\title{
Website Based Information System for Sales and Purchasing of Traditional Fish for Kalanganyar Residents
}

\section{Sistem Informasi Penjualan dan Pembelian Ikan Tradisional Berbasis Website Pada Warga Kalanganyar}

\author{
$1^{\text {st }}$ Ahmad Rizqi Efendi ${ }^{1}, 2^{\text {nd }}$ Yulian Findawati ${ }^{2}$ \\ \{rizqiefendi088@gmail.com ${ }^{1}$, yulianfindawati@umsida.ac.id ${ }^{2}$ \}
}

Universitas Muhammadiyah Sidoarjo, Indonesia ${ }^{1}$ Universitas Muhammadiyah Sidoarjo, Indonesia ${ }^{2}$

\begin{abstract}
The purpose of this research is to create an information system that can be used for buying and selling websites. The research method used is the waterfall method, but the data collection techniques used are observation, interviews, and literature study. Where to get the data, it is necessary to come directly to the location which is the place of research. Later, the result of this research is that circles of people can sell products online and can expand the reach of website based marketing, buyers only need to access the website to make purchase transactions.
\end{abstract}

Keywords - sales, buying, marketing, information

\begin{abstract}
Abstrak. Tujuan dari penelitian ini adalah menciptakan sebuah sistem informasi yang dapat digunakan untuk jual dan beli yang bersifat websit. Metode penelitian yang digunakan itu adalah metode waterfall, tetapi tehnik pengumpulan data yang digunakan menggunakan observasi, wawancara, dan study pustaka. Dimana untuk mendapatkan datanya perlu untuk datang langsung ke lokasi yang menjadi tempat penelitian. Nantinya hasil dari penelitian ini ialah warga kalanganyar dapat untuk menjual produk secra online dan dapat memperluas jangkauan pemasaran yang dilakukan berbasis website, pembeli tinggal mengakses website untuk melakukan transsaksi pembelian.
\end{abstract}

Kata Kunci - penjualan, pembelian, pemasaran, informasi

\section{Pendahuluan}

Perkembangan teknologi yang terjadi pada saat ini sangatlah pesat baik didalam maupun diluar dan dapat untuk memudahkan manusia untuk melakukan kegiatan sehari- hari seperti manusia berinteraksi dengan manusia lainya yang jaraknya sangat jauh seperti terpisah dengan pulau [1]. Internet bisa memberikan segalanya seperti informasi tentang semua yang di butuhkan oleh manusia. Internet selain memberikan infomasi juga dapat digunakan untuk pencarian data sehingga dapat memudahkan aliran informasi dan komunikasi yang dibutuhkan oleh banyak orang [4]. Dalam menggunakan media sistem informasi dapat membuat hubungan yang kuat antara perusahaan dan konsumen yang prosesnya akan menjadi lebih gampang dan efektif [5].

Desa kalanganyar dalam melakukan penjualan jangkauan untuk menjualnya tidaklah luas biasanya hasil panen ikan di jual ke warga kalanganyar sendiri unutk di pasarkan kembali oleh para pedagang pemasaran yang dilakukan oleh pedagang adalah menggunakan cara tradisional yaitu menjual produk di tempat yang tersdia di desa seperti pasar pembeli yang ingin membeli harus datang ke tampat tersebut untuk melakukan pembelian. Dengan memanfaatkan sistem penjualan dan pembelian berbasis website bertujuan supaya dapat meningkatkan pelayanan kepada pembeli yang ingin membeli dan memberikan kenyamanan karena cara unutk membelinya tidak harus untuk datang ke toko melainkan cukup dengan membuka website untuk melakukan proses transaksi pembelian [10].

Jangkauan penjualan yang dapat mendapat pelanggan yang banyak atau jangkauan yang luas merupakan hal yang sangat penting dalam melakukan penjualan, namun ada juga yang harus diperhatikan dalam aspek - aspek yang ada yaitu aspek efisiensi biaya [2]. Memasarkan produk menggunakan media website memiliki banyak keuntungan selain menguntungkan juga dapat memudahkan dalam proses pengembangan dan dapat menghemat biaya [6]. Fungsi dari sistem informasi penjualan dan pembelian itu sangatlah penting sebagai tempat yang dapat membantu pihak perusahaan dalam memberikan suatu informasi yang di sampaikan kepada konsumen dari produk itu sendiri. Supaya konsumen mengetahui kelebihan dan kekurangan produk yang dijual [7].

Banyaknya pengerajin dan penjual batik skala kecil pembuatan dan penjualanya masih menggunakan cara klasik dan sederhana, dalam memasarkan batik di pasarkan ke pasar - pasar tradisional. Meskipun sampai saat ini cara yang dilakukan masih berjalan dengan baik [3]. Maka internet menjadi media alternatif unutk menjalankan suatu usaha. Selain media informasi dan komunikasi internet juga dimanfaatkan untuk proses penjualan dan pembelian produk yang dikenal dengan toko online [8]. E-commerce biasanya digunakan sebagai pendukung dalam melakukan kegiatan penjualan dan pembelian dan dapat menampilkan informasi dari produk yang ingin di jual konsumen dapat dengan mudah untuk melakukan proses transaksi pembelian [9]. 


\section{METODE}

\section{A. Objek Penelitian}

Tempat dilaksanakan penelitian terletak di desa kalanganyar sedati sidoarjo yang berlokasi di Jl. Raya kalanganyar, Rt. 18 Rw. 04, Kec. Sedari, Kab. Sidoarjo. Didalam desa terdapat banyak para pedagang yang penjualanya masih menggunkan sistem tradisional yaitu dengan cara pembeli datang langsung ke pasar jika pembeli memiliki kesibukan itu akan mempersulit untuk melakukan pembelian, jadi tempat objek unutk melakukan penelitian yang berada di desa kalanganyar adalah tepat.

\section{B. Analisa Sistem}

Sisem yang dibuat tidak jauh dari kondisi yang ada dalam desa kalanganyar yaitu cara pemasaranya yang masih menggunakan sistem tradisional. Oleh karena itu menciptakan sebuah sistem pemasaran online yang dapat mempermudah dan memperluas jangkauan untuk melakukan pemasaran dan penjualan, ada tiga cara dalam pengambilan dtanya yaitu observasi teknik yang sangat penting untuk membantu penelitian. Teknik observasi adalah melakukan sebuah kegiatan dengan tujuan mengumpulkan data melalui pengamatan dari kejadian yang berada di sekitar desa kalanganyar, seperti tanda, kejadian, dan hal - hal yang berkaitan dengan permasalahan yang ada. Wawancara juga sangat penting karena menjadi salah satu cara untuk mengumpulkan informasi dalam penelitian yang dilakukan, dengan cara langsung datang ke tempat lokasi untuk mencari informasi dari orang- orang yang menjual produk dengan cara tradisional dengan caara memberi beberapa pertanyaan setelah itu mendengarkan jawaban dari orang yang di beri pertanyaan lalu jawaban tersebut akan diambil point - poin penting yang diperlukan dalam proses pengumpulan data. Studi pustaka adalah cara mengumpulkan data dengan melalui dokumen dengan membuat studi penelitian yang ada di buku, literatur, catatan, dan laporan yang tersedia ke permasalahan yang dihasilkan.

\section{Diagram Alur Aplikasi}

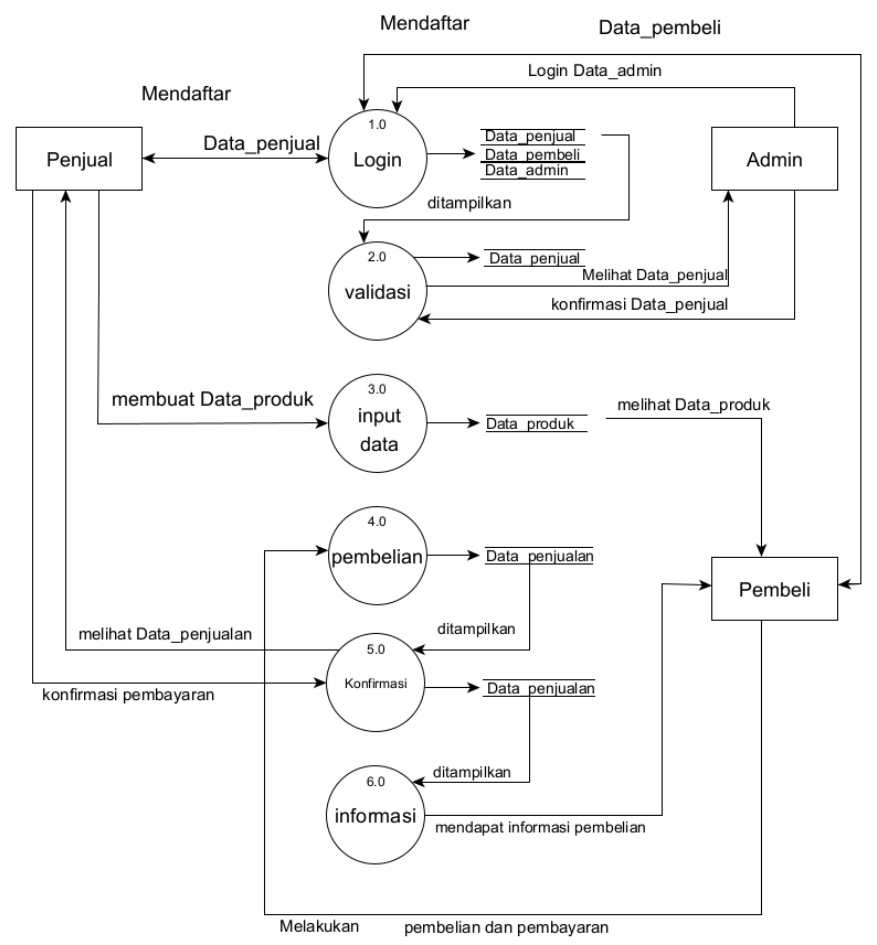

Gambar 1. Data Flow Diagram

Pada tampilan gambar data flow diagram dapat mewakilkan salah satu dari banyaknya rancangan yang ada dalam website yang akan di bangun, didalam data flow diagram dapat diartikan bahwa pertama admin akan melakukan login terlebih dahulu setelah admin sudah login admin memiliki akses untuk memvalidasi dari pendaftaran penjual kemudian setelah pendaftaran penjual sudah di validasi penjual akan melakukan login lalu penjual akan memasukkan produk yang akan di jual ke dalam sistem. Hasil dari produk yang sudah di masukkan akan di lihat oleh pembeli tapi sebelum itu pembeli harus melakukan login terlebih dahulu, jika pembeli tertarik dengan produk yang di jual pembeli akan melakukan pembelian setelah itu melakukan pembayaran dan akan tersimpan ke dalam tabel data penjualan, transasksi yang sudah dilakukan oleh pembeli akan dilihat oleh penjual dan penjual akan mengkonfirmasi pembayaran yang sudah di kirim oleh pembeli. Kemudian pembeli dapat melihat informasi terbaru tentang status transaksi yang dilakukan. 
Procedia of Engineering and Life Science Vol. 1. No. 2 Juni 2021

Seminar Nasional \& Call Paper Fakultas Sains dan Teknologi (SENASAINS $2^{\text {nd }}$ )

Universitas Muhammadiyah Sidoarjo

\section{Perancangan Antar Muka Website Penjualan dan Pembelian Online}

Rancangan adalah salah satu juga hal yang penting supaya dapat dilihat hasil kasar dari website yang akan dibuat, perancang juga membuat desain senidri untuk website pemasaran penjualan dan pembelian dalam rancangan tersebut terdapat tiga gamba dari tampilan utama masing masing seperti pada Gamabar 2 adalah tampilan dari admin setelah admin melakukan login terdapat berbagai menu yang ada yaitu seperti profil, validasi, ongkos kirim, data penjual, data pembeli dan juga logout. Kemudian pada Gambar 3 adalah tampilan utama dari penjual setelah melakukan login didalamnya terdapat menu profile, profile toko,data produk, penjualan, laporan, dan grafik. Kemudian untuk Gambar 4 adalah tampilan dari pembeli saat setelah login, pemeli akan langsung di berikan informasi seputar produk yang akan di jual dan terdapat menu juga yaitu beranda, produk, keranjang, pesanan, profile, dan tentang kami.

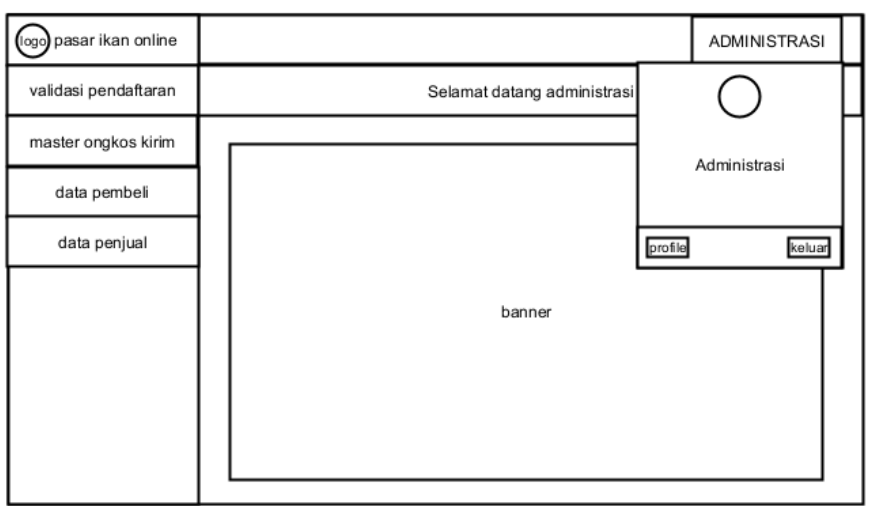

Gambar 2. Rancangan antarmuka pada tampilan utama admin

\begin{tabular}{|c|c|c|c|c|}
\hline (190) pasar ikan online & & & & JUAL \\
\hline profil toko & \multicolumn{2}{|l|}{ SELAMAT DATANG } & \multirow{3}{*}{\multicolumn{2}{|c|}{ Nama Toko }} \\
\hline data produk & & \multirow{10}{*}{ BANNER } & & \\
\hline penjualan & & & & \\
\hline konfirmasi transfer & & & PROFILE & $\overline{\text { KELUAR }}$ \\
\hline data penjualan & & & & \\
\hline Laporan & & & & \\
\hline penjualan & & & & \\
\hline produk terjual & & & & \\
\hline grafik & & & & \\
\hline pendapatan & & & & \\
\hline & & & & \\
\hline
\end{tabular}

Gambar 3. Rancangan antarmuka pada tampilan penjual

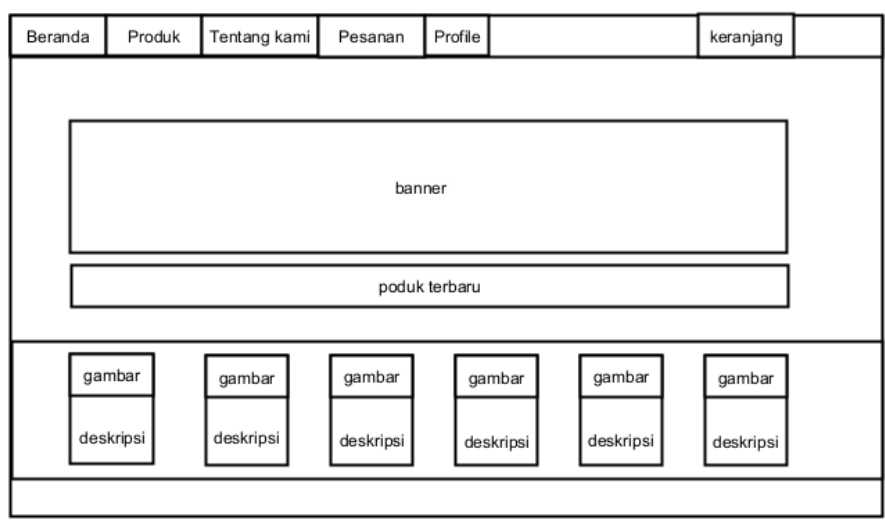

Gambar 4. Rancangan antarmuka pada tampilan pembeli 
Procedia of Engineering and Life Science Vol. 1. No. 2 Juni 2021

Seminar Nasional \& Call Paper Fakultas Sains dan Teknologi (SENASAINS 2nd)

Universitas Muhammadiyah Sidoarjo

\section{HASIL DAN PEMBAHASAN}

\section{A. Implementasi Antarmuka Website Penjual}

Pada tampilan implementasi antarmuka website penjual akan memperlihatkan bagaimana cara penjual dalam menamnahkan produk dan mengkonfirmasi transaksi yang dilakukan oleh pembeli, berikut adalah tampilan diantaranya :

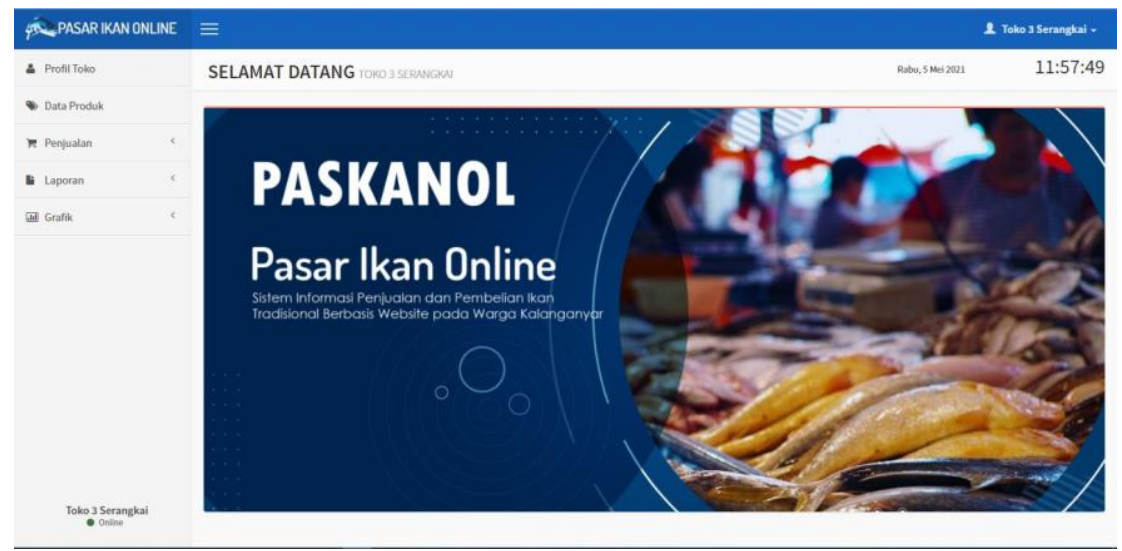

Gambar 5. Tampilan beranda penjual

Pada tampilan pertama kali login penjual akan di tampilkan dengan tampilan selamat datang kemudian di dalamnya juga terdapat berbagai menu yaitu profil, profil toko, data produk, penjualan, laporan, dan grafik.

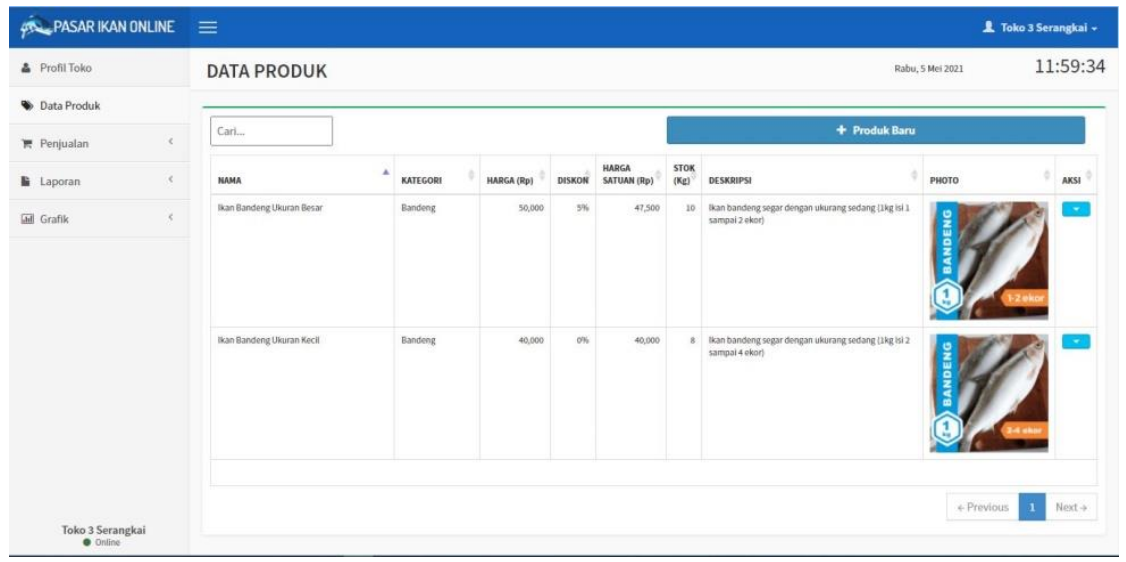

Gambar 6. Tampilan data produk

Pada tampilan menu data peroduk adalah menu yang bertugas untuk memasukkan produk yang ingin di jual di website untuk menambah produk pilih tombol tambah produk.

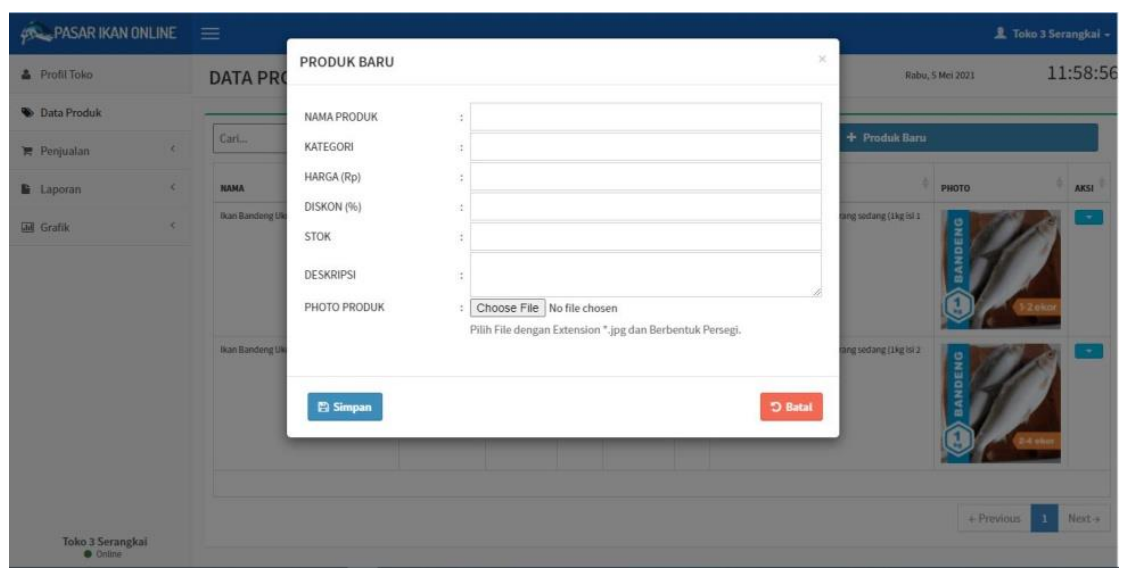

Gambar 7. Tampilan tambah produk 
Procedia of Engineering and Life Science Vol. 1. No. 2 Juni 2021

Seminar Nasional \& Call Paper Fakultas Sains dan Teknologi (SENASAINS 2nd)

Universitas Muhammadiyah Sidoarjo

Pada tampilan tombol tambah produk akan di suruh mengisi form yang ada yaitu nama produk, kategori, harga, diskon, stok, deskripsi, dan gambar produk. Jika selesai klik tombol simpan

\begin{tabular}{|c|c|c|c|c|c|c|c|}
\hline \multirow{3}{*}{$\begin{array}{l}\text { E Penjualan } \\
\star \text { Konfirmasi Transfer } \\
\text { E Data Penjualan }\end{array}$} & \multirow{3}{*}{$\begin{array}{l}\checkmark \\
\text { (1) }\end{array}$} & \multicolumn{2}{|l|}{ Cari... } & \multirow[b]{2}{*}{ of } & \multirow[b]{2}{*}{ NAMA PELANGGAN } & \multirow[b]{2}{*}{$\hat{y}$} & \multirow[b]{2}{*}{ NOMOR FAKTUR } \\
\hline & & AKSI ${ }^{*}$ & TANGGAL & & & & \\
\hline & & & 2021-05-05 & & \multirow[t]{2}{*}{ Arief Pradipta } & & \multirow[t]{2}{*}{ NF-0015 } \\
\hline E Laporan & $<$ & & $\begin{array}{l}\text { Pembayaran Telah Diterima } \\
\text { Hapus }\end{array}$ & & & & \\
\hline IIII) Grafik & $<$ & & & & & & \\
\hline
\end{tabular}

Gambar 8. Tampilan konfimasi pembayaran

Pada tampilan menu konfirmasi transfer penjual akan mengkonfirmasi pembyaran yang sudah di kirim oleh pembeli dengan cara klik di aksi lalu pilih pembayaran telah di terima.

\section{B. Implementasi Antarmuka Website Pembeli}

Pada tampilan implementasi antarmuka dari pembeli akan memberikan proses transaksi pembelian dari awal sampai sudah kirim pembayaran

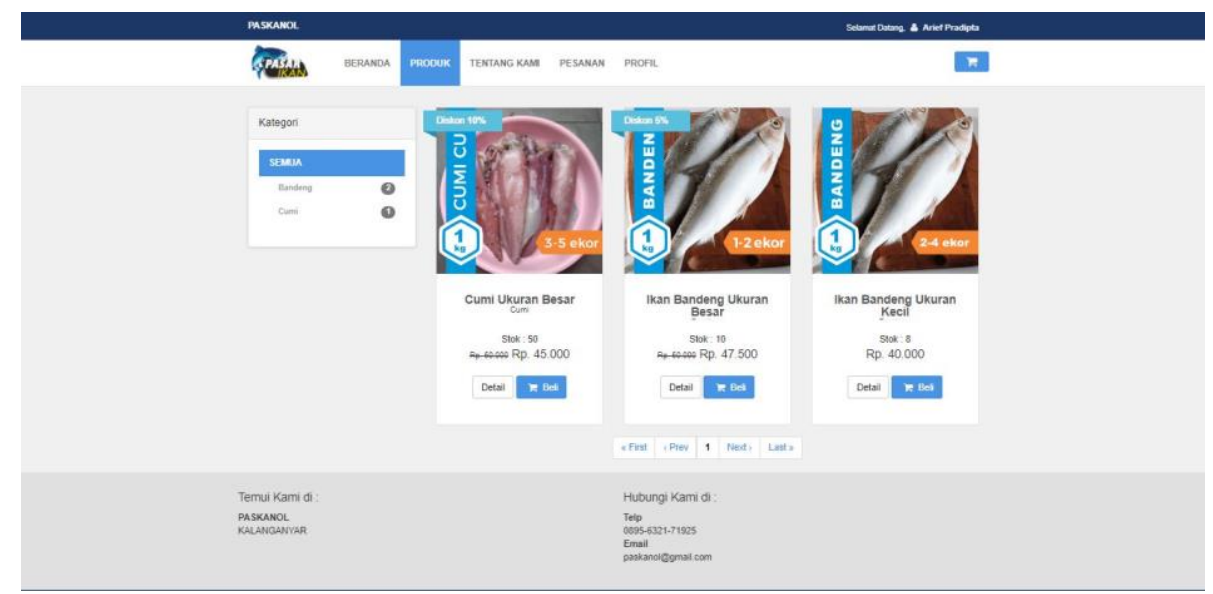

Gambar 9. Tampilan produk

Pada tampilan menu produk pembeli pembeli akan di tampilkan langsung dengan produk yang di jual oleh penjual jika pembeli ingin membeli tinggal mengklik tombol beli

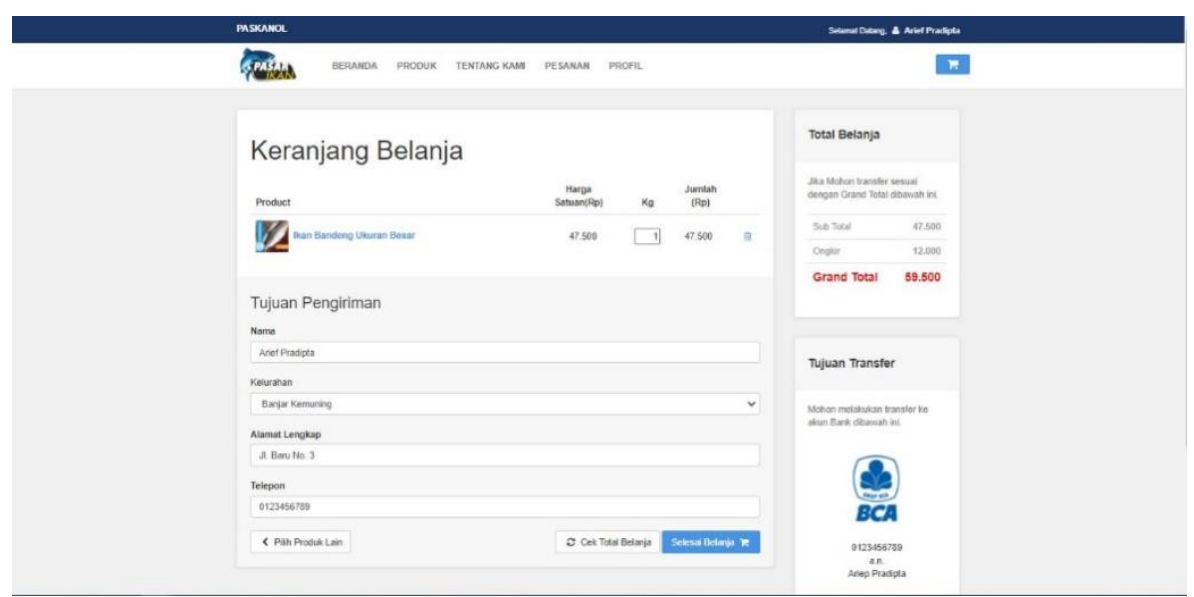

Gambar 10. Tampilan keranjang 
Procedia of Engineering and Life Science Vol. 1. No. 2 Juni 2021

Seminar Nasional \& Call Paper Fakultas Sains dan Teknologi (SENASAINS $2^{\text {nd }}$ )

Universitas Muhammadiyah Sidoarjo

Pada tampila keranjang pembeli akan dilihatkan informasi harga dan ongkir pembelian yang akan di lakukan jika alamat sudah benar langusng tekan selesai belanja dan transfer uang ke nomer rekening yang berada di bawah kanan.

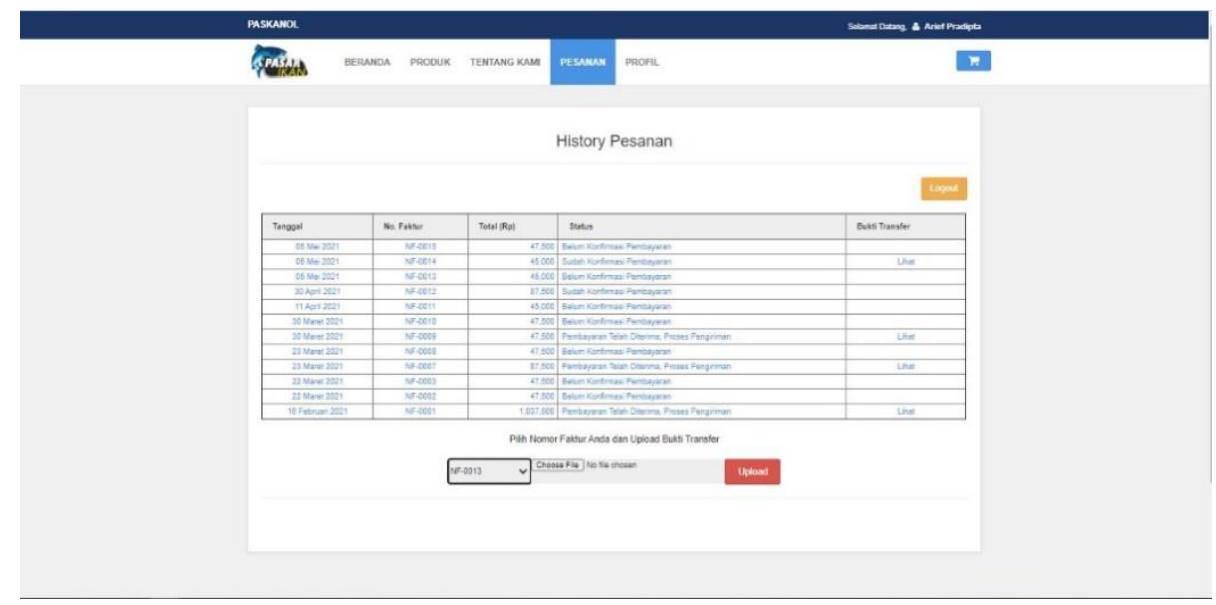

Gambar 11. Tampilan pesanan

Pada tampilan pesanan pembeli akan di lihatkan seputar informasi tentang transaksi yang di dalamya ada tanggal, no faktur, total harga, dan status transaksi. Kemudain untuk mengirim bukti pembayaran ada di bagian bawah klik choose file lalu upload.

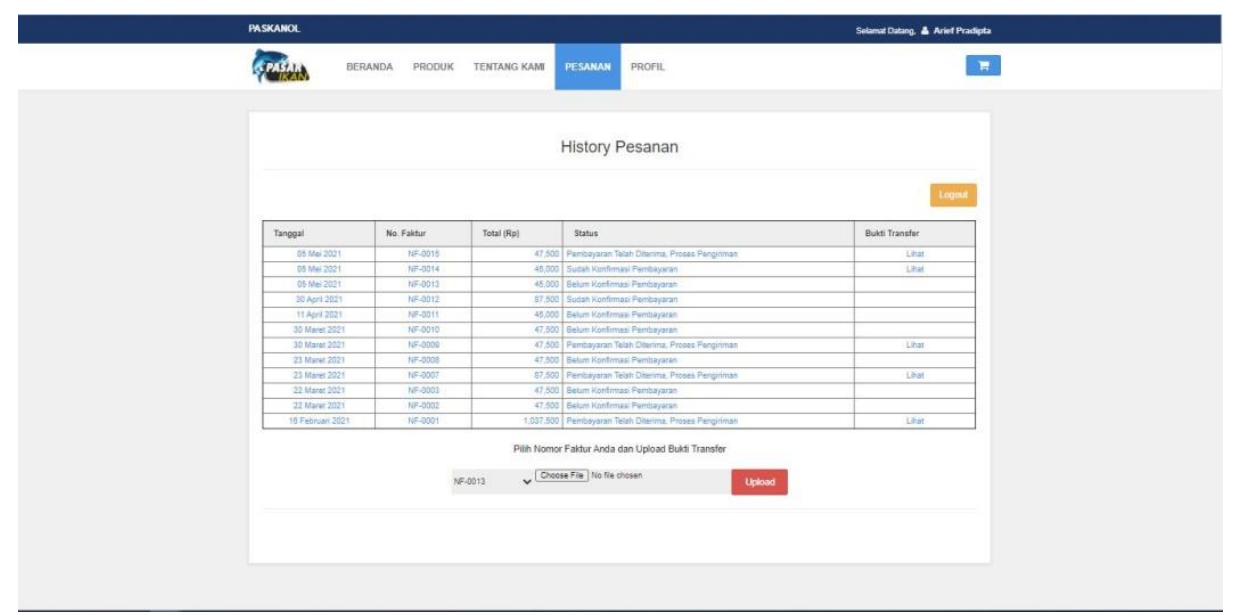

Gambar 12. Tampilan sudah di konfirmasi pembayaran

Pada tampilan ini adalah tampilan setelah penjual sudah mengkonfirmasi pembayaran yang sudah dikirim oleh penjual status akan berubah mejadi prmbayaran telah diterima, proses pengiriman. 


\section{KESIMPULAN}

Berdasarkan dari hasil yang sudah dilakukan kesimpulan yang didapat adalah meskipun menggunakan website tetapi pengiriman hanya berada di dalam kecamatan sedati tapi meskipun begitu website pemasaran ini akan menjadi awal dari cara kemajuan cara penjualan yang berada di desa kalanganyar dan dapat mempermudah dalam melakukan transaksi lalu mengurangi keramaian karena pembeli tidak perlu untuk datang langsung ke pasar jika ingin membei produk.

\section{Referensi}

[1] Muslihudin.M, Fauzi, indonesia : STMIK Pringsewu Lampung, Sistem Informasi Penjualan Batik Basurek Berbasis Web Pada Basurek Collection Bengkulu, 2017

[2] Hidayat Kurniawan Miwan, Ningrum Pangestu Catur Retno, IJCIT : Indonesia Journal on Computer and Information Technology, Sistem Informasi Penjualan Online Pada Toko Yusuf Bekasi, 2017

[3] Himawan, Saefullah Asep, Santoso Sugeng, Indonesia : STMIK Raharja Tangerang, Analisa dan Perancangan Sistem Informasi Penjualan Online (E-Commerce) Pada CV Selaras Batik Menggunkan Analisa Deskriptif, 2014

[4] Mustofa Ahmad, Mutmainah, indonesia : STMIK Pringsewu Lampung, Perancangan E-commerce Penjualan Komputer dan Alat Elektronik Berbasis Web Pada Toko Damar Komputer Pringsewu, 2015

[5] Kholil Ishak, indonesia : STMIK Nusa Mandiri Jakarta, Costomer Relationship Management (CRM) Berbasis Web Untuk Meningkatkan Daya Saing Toko Online, 2017

[6] Hastanti Puji Rulia, Purnama Eka Bambang, Wardati Uly Indah, Universitas Surakarta : STMIK Nusa Mandiri Jakarta, STKIP PGRI Pacitan, Sistem Penjualan Berbasis Web (E-commerce) Pada Tata Distro Kabupaten Pacitan, 2015

[7] Lesmana Yandri, Mahendra Muklis, Miranda S Are, Khailizah, Purnama Iwan, Fakultas Sains dan Teknologi, Teknologi Informasi, Universitas Labuhanbatu, Labuhanbatu, indonesia, Rancang Toko Online Perabot Berbasis Web, 2020

[8] Aryanto Arip, Tjendrowasono Irianto Tri, Fakultas Teknologi Informatika Universitas Surakarta, Pembangunan Sistem Penjualan Online Pada Toko Indah Jaya Furniture Surakarta, 2012

[9] Firmansyah Novianti Nita, Mulyani Asri, Sekolah Tinggi Teknologi Garut, Rancang Bangun Aplikasi Penjualan Online Berbasis Web Pada Toko Spiccato Bandung, 2017

[10] Nasution Angeline, Baldawi Taufik, Sistem Informasi : STMK Nusa Mandiri Jakarta, Manajemen Informatika : AMIK BSI Sukabumi, Sistem Informasi Penjualan Obat Bebasis Web Pada Apotek Perwira Jaya Bekasi, 2016 